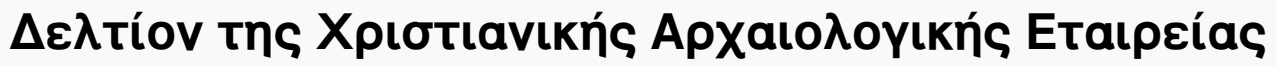

Tó 12 (1986)

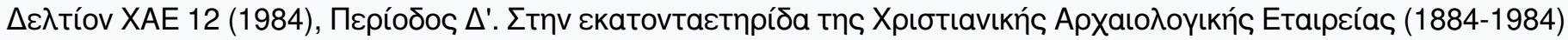

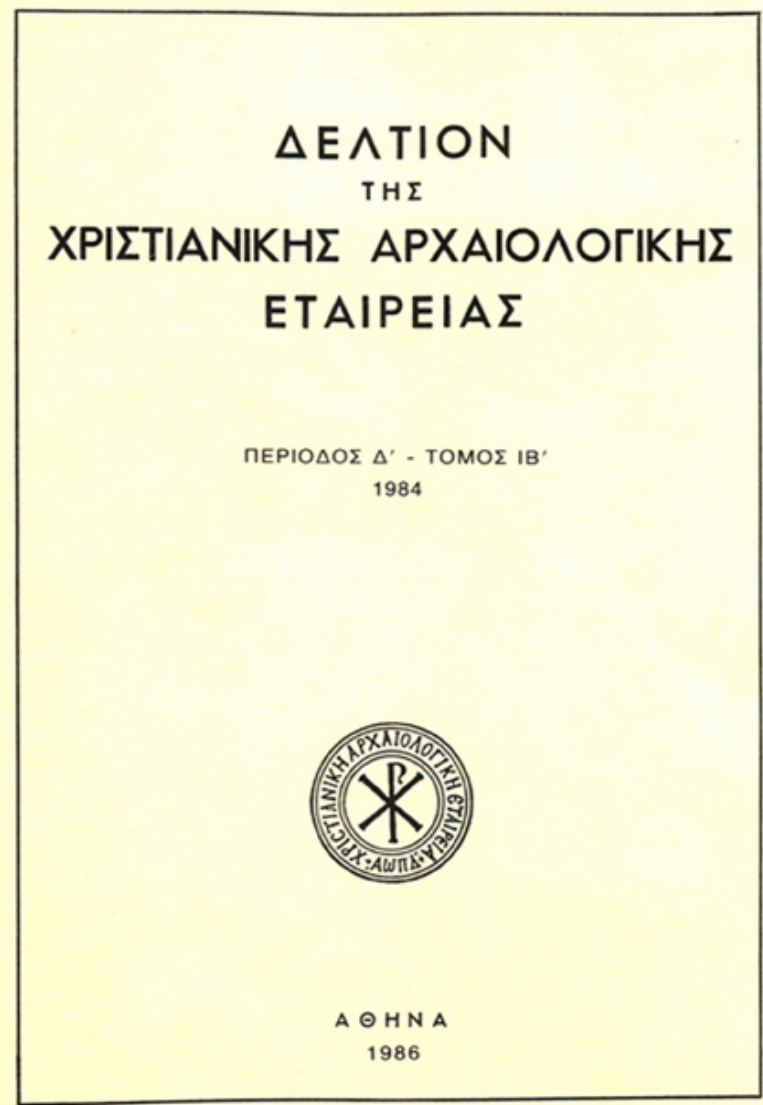

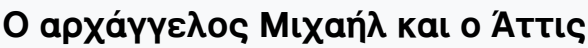

Cyril MANGO

doi: $10.12681 /$ dchae.946

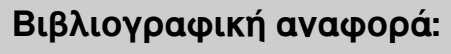

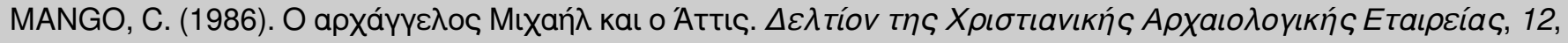
39-62. https://doi.org/10.12681/dchae.946 


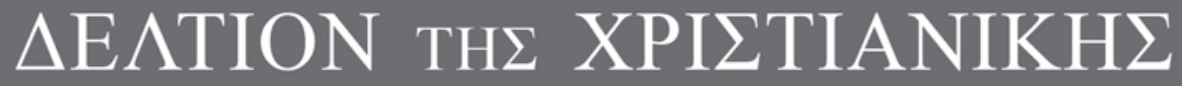 APXAIO $\Lambda$ OГIKH $\Sigma$ ETAIPEIA $\Sigma$}

St. Michael and Attis

Cyril MANGO

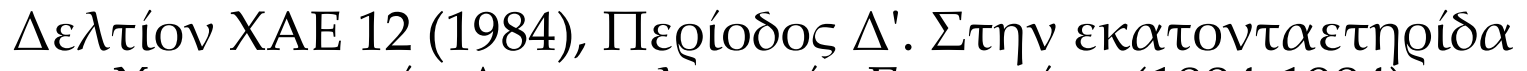

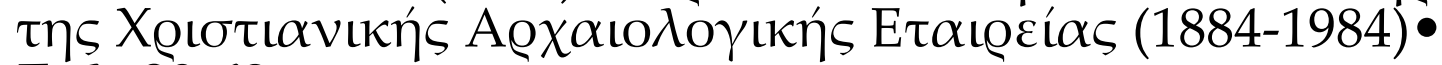
$\Sigma \varepsilon \lambda .39-62$

A@HNA 1986 


\section{ST. MICHAEL AND ATTIS}

Twenty years ago, when I was working on the apse mosaics of St. Sophia at Constantinople, I had ample opportunity to contemplate what is surely one of the most beautiful works of Byzantine art, I mean the image of the archangel Gabriel, who stands next to the enthroned Theotokos (Fig. 1). Gabriel is dressed in court costume; indeed, one can affirm that his costume is imperial, since he is wearing red buskins and holding a globe, the symbol of universal dominion. Yet neither the Bible nor orthodox doctrine as defined by the Fathers provides any justification for portraying an archangel in this guise; no matter how great was his dignity in heaven, he remained a minister and a messenger ${ }^{1}$. Only God could be described as the equivalent of the emperor. How was it then that Byzantine art, which showed extreme reluctance to give to Christ, the pambasileus, any visible attributes of royalty other than the throne, granted these very attributes to archangels, who had no claim to them?

An enquiry I undertook at the time (and left unpublished) suggested the following conclusions:

1. The Byzantines themselves, I mean the medieval Byzantines, could offer no reasonable explanation of the iconography of archangels and seemed to be unaware of its meaning. On the subject of the globe I found only two texts. One was an unedited opuscule by Michael Psellos, who, quite absurdly, considered it to denote the angels' rapidity of movement; "for", he says, "the sphere is such an object that, touching as it does only a tiny portion of the ground, is able in less than an instant to travel in any direction" ${ }^{2}$. The other text was a commentary by Symeon of Thessalonica, who, having in mind the art of his own period (Fig. 2), thought that the "cloudlike circular object" (

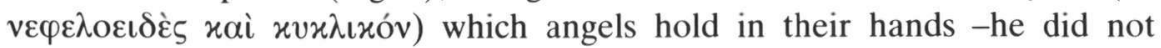
recognize it as a globe- signified the sanctification of the Spirit and was, furthermore, a symbol of $\theta \varepsilon 0 \lambda \sigma \gamma i$ i (the knowledge of God) inasmuch as God, like the circle, has neither beginning nor end ${ }^{3}$.

1. It is enough to quote the definition of Eusebius, Praep. evang., VII, 15, 18: Christians,

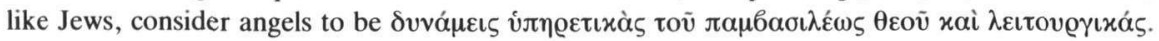

2. This text, which is found in Sinait. gr. 482 (1117), Bodl. Auct. F. 6.26 and other manuscripts, is soon to be published by Prof. H. K. Snipes, whom I should like to thank for

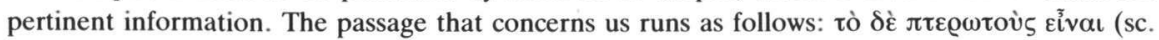

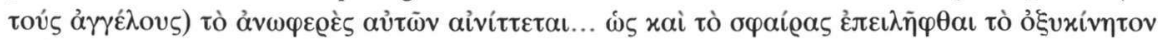

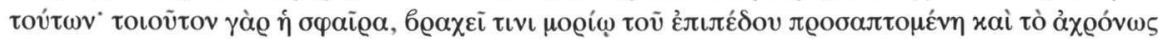

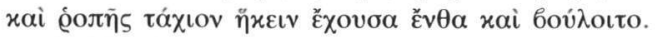

3. PG 155,869 C-D. 


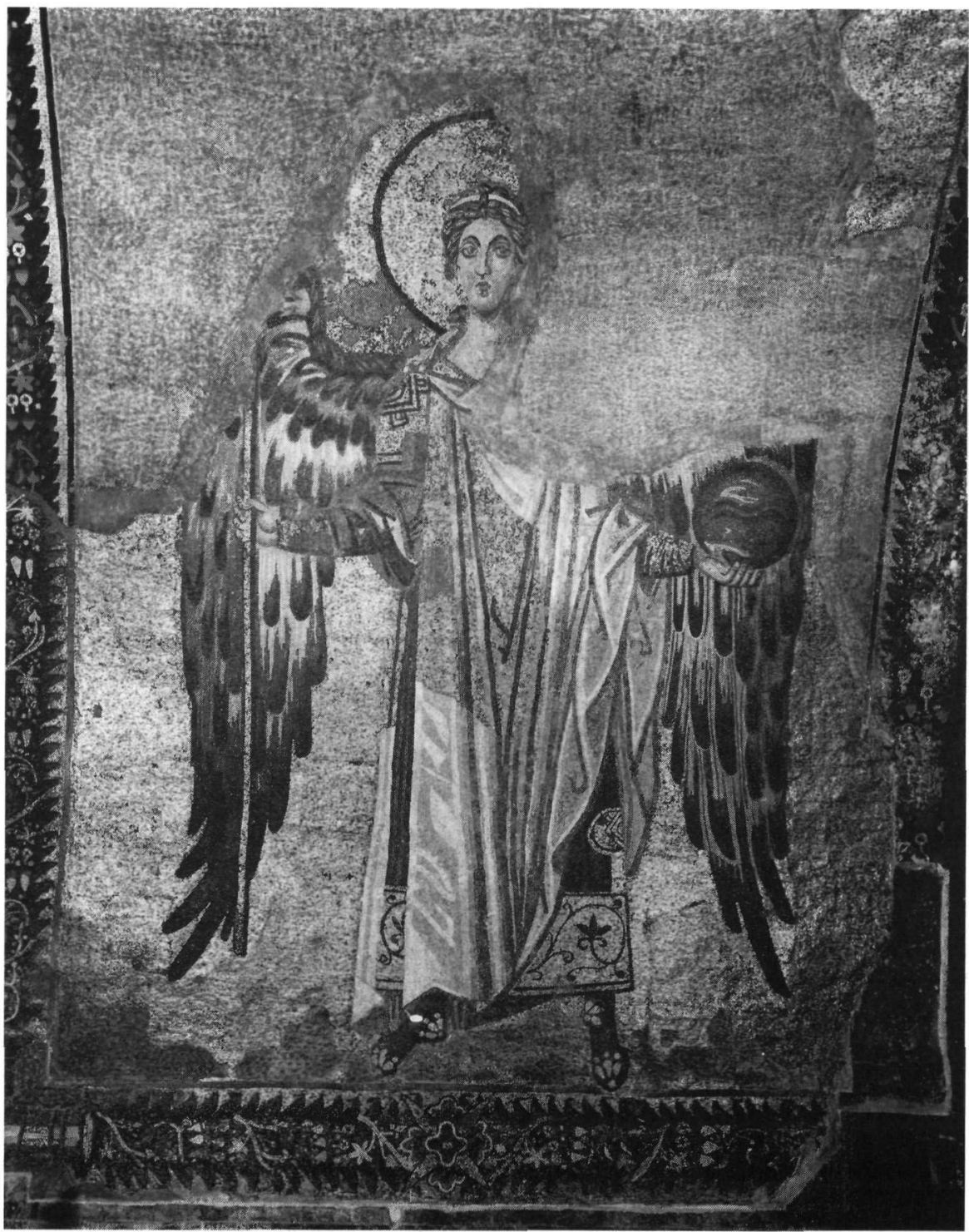

Fig. 1. St. Sophia, Constantinople. Archangel Gabriel in the bema. Photo Dumbarton Oaks.

2. The imperial iconography of archangels is traceable to the pre-Iconoclastic period and was already established by about the year 500 . Indeed, Severus, patriarch of Antioch from 512 to 518, was accused by his opponents of arguing in the very church of St. Michael that white vestments, not purple ones, were 


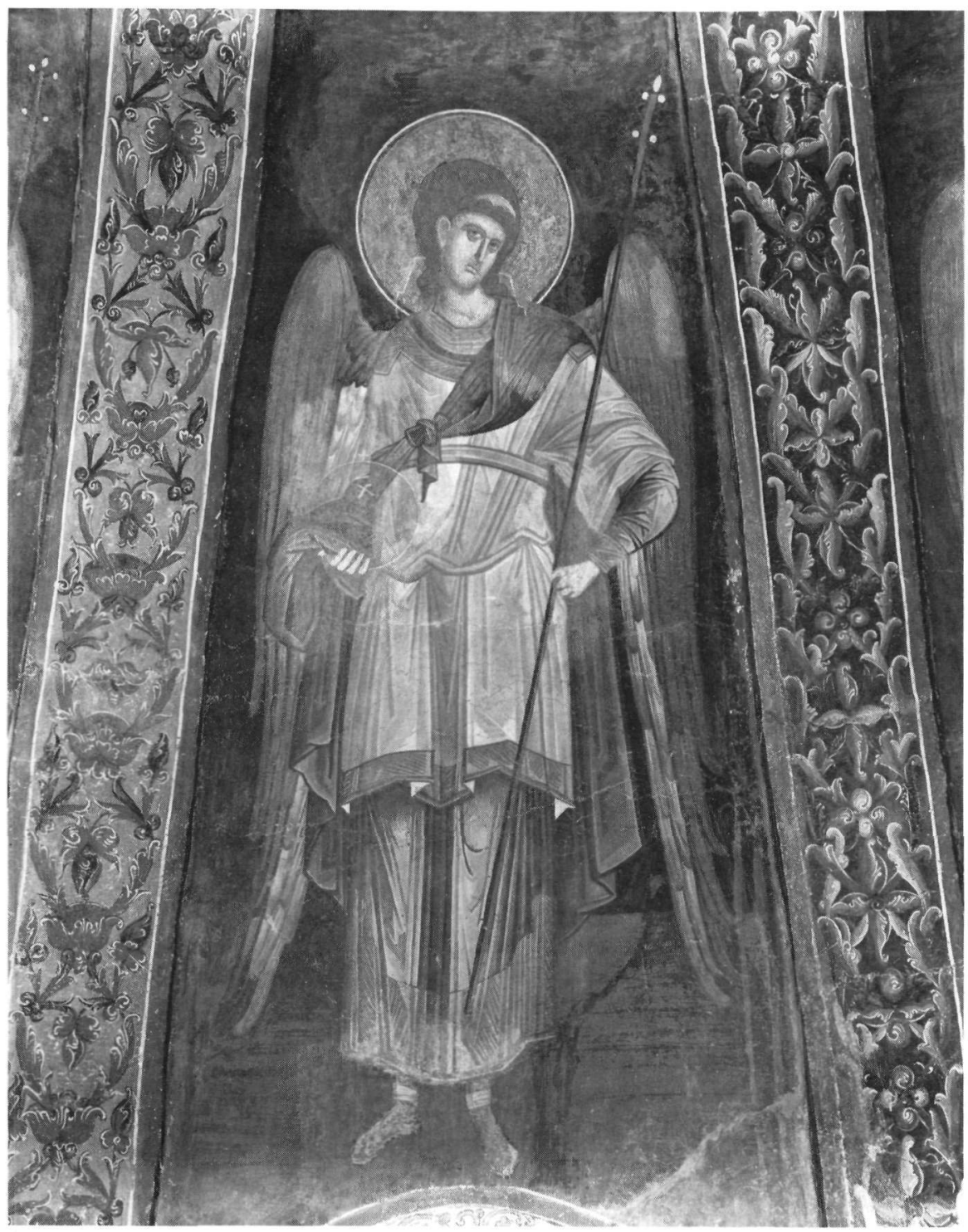

Fig. 2. Kariye Camii, parekklesion. Angel in the dome. Photo Dumbarton Oaks.

appropriate to angels ${ }^{4}$. We are fortunate in possessing his actual text, in which he says: "The insolent hand of painters, favouring as it does the inventions of

4. John of Gabala, Life of Severus, as quoted at the Seventh Oecumenical Council, Mansi, XIII, 184C. 


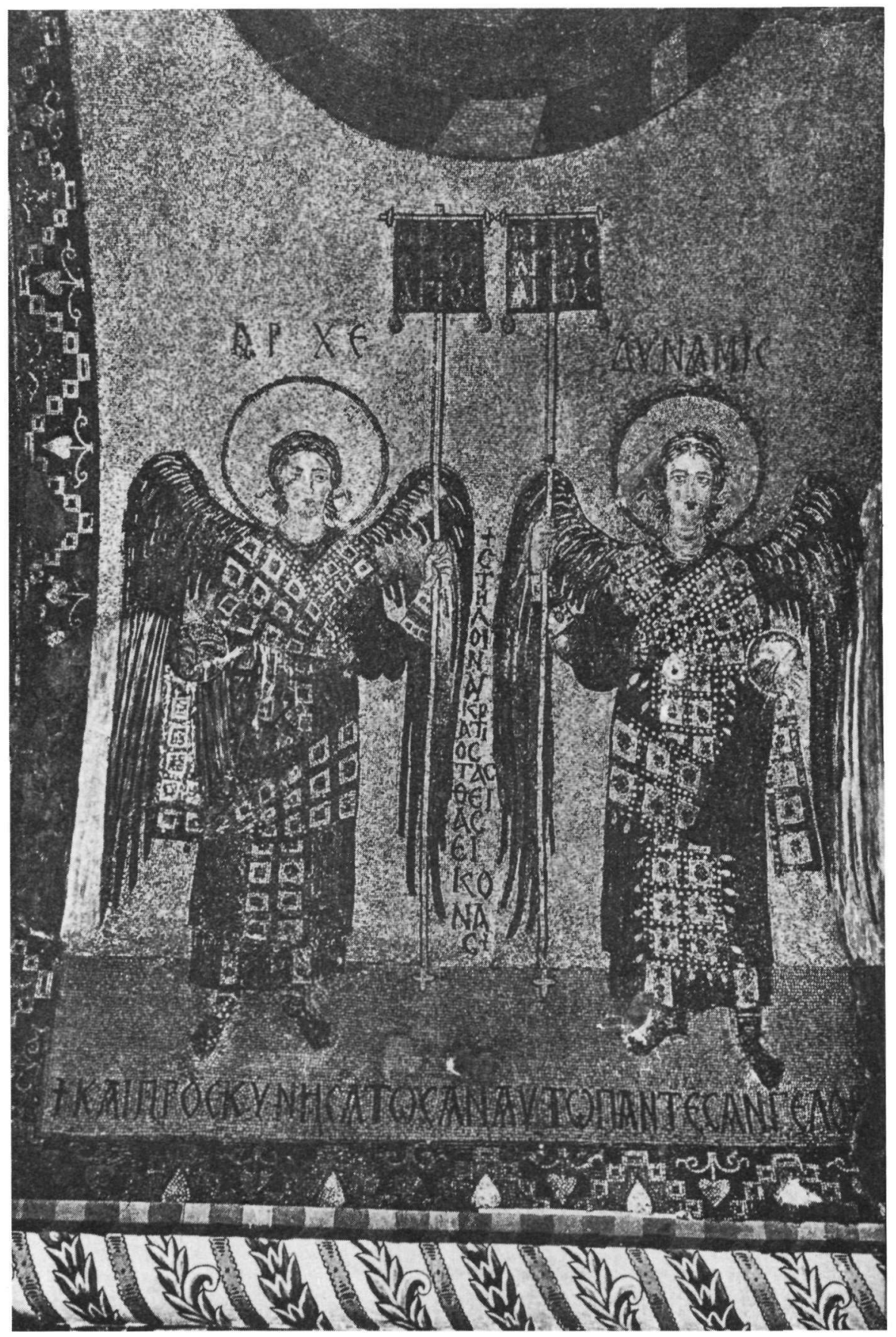

Fig. 3. Nicaea, Koimesis church. Angelic powers in the bema. 


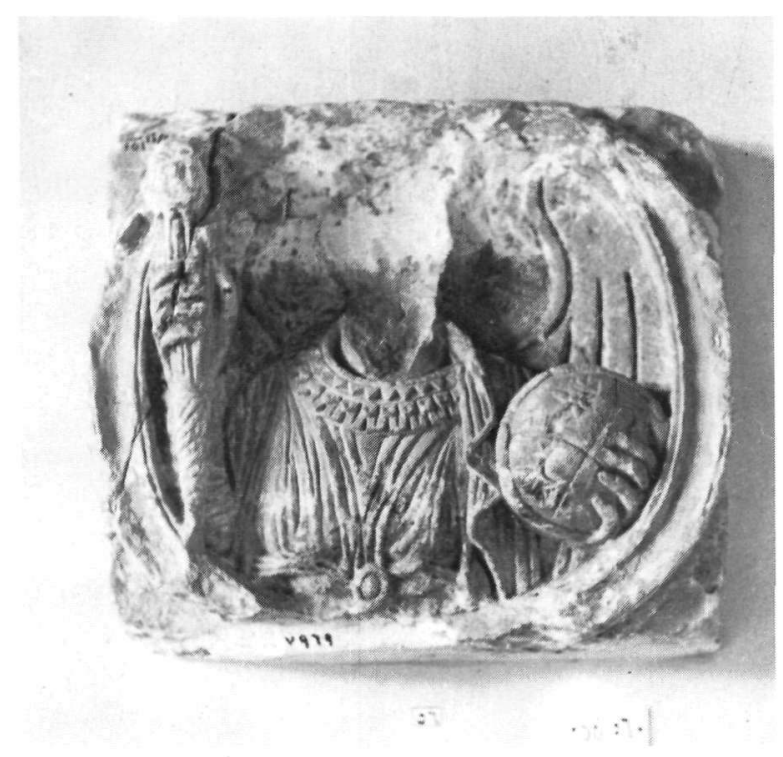

Fig. 4. Cairo, Coptic Museum. Relief of archangel.

pagans, decks out Michael and Gabriel, like princes and kings, in a robe of royal purple, adorns them with a crown and places in their right hand the token of universal authority" 5 .

Unlike the later Byzantine commentators, Severus (who, significantly, was a native of Pisidia) had a clear understanding of the meaning of that iconography and of its pagan overtones. Among preserved works of art, we find an archangel in purple in the church of S. Apollinare in Classe near Ravenna; while the destroyed mosaics of the church of the Dormition at Nicaea, which probably dated from immediately after Iconoclasm, portrayed the angelic powers with loros and globe (Fig. 3), just as the emperor was represented in the same period (compare, e.g., the mosaic portrait of the Emperor Alexander in the gallery of St. Sophia).

3. The globe which, with a little ingenuity, could have been explained away as a different kind of object (e.g. the seal of God) ${ }^{6}$, certainly denoted

5. Homiliae cathedrales, trans. M. Brière, Patr. orient., XII/1, 1919, 83-84. Severus' intention, which was perfectly orthodox, was to 'dilute' the cult of angels (worshipped by Jews, pagans and even some Christians) with that of the martyrs.

6. Scriptural or parascriptural authority for such an interpretation could have been found in

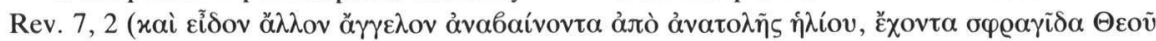
$\zeta \tilde{\omega} v \tau o \zeta)$ and the Odes of Solomon, 4, 8. The idea is developed in a Coptic encomium ascribed to a certain Eustathius, bishop of Trakê, trans. E. A. Wallis Budge, Saint Michael the Archangel, London 1894, 102*, 97*-98*, in which St. Michael appears holding in his left hand "a wheel [or 
originally the universal orb, as proved by the presence on it of celestial symbols (sun, moon and stars) and by the diagonal lines of the horizon and the ecliptic (Fig. 4). In the course of the Middle Ages it underwent a transformation, gradually losing both its sphericity and its translucence to become a flat disk upon which the cross or various initials were often inscribed, but it regained transparency in the Palaeologan period. The fact that the orb did not exist as an actual item of the Byzantine imperial regalia may explain the inability of Byzantine commentators to recognize it as such in the hand of archangels.

4. As a rule, the imperial iconography of archangels never appears in narrative scenes, either biblical or hagiographic. When St. Michael manifests himself to Joshua, he is in military dress, as the text specifies. In the Annunciation the archangel Gabriel is represented, if I may say so, 'normally' as is also the angel who struggles with Jacob. Even in the story of the miracle of Chonai St. Michael has no royal attributes ${ }^{7}$. The latter appear only in static or 'iconic' images.

5. Whenever angels and archangels make themselves manifest in the Lives of saints and other edifying texts they do so in the guise of eunuchs or imperial cubicularii, not that of emperors ${ }^{8}$. Their imperial iconography cannot, therefore, be attributed to the influence of popular orthodox devotion.

In the light of the above considerations and the well-known role of archangels in the world of Late Antique, particularly Jewish magic and

disk], like [that of] a chariot, upon which was a cross". The significance of the cross is explained as follows: "For no man will fulfil the behest for which any soldier hath come from the Emperor... unless he bear the token of the Emperor; and, moreover, thus it is with the letters which the Emperor sendeth forth from his kingdom, no man believeth that they are genuine unless they be sealed with the Emperors seal; and thus also it is with the angels who come upon the earth, for if the figure of the Cross of the King of Glory be not with them, men will not believe that they are angels... and especially in the case of the Archangel of all the angels, for how could he come upon the earth without bearing the armour of the seal of salvation of his Emperor?". In Dionysios of

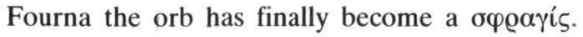

7. Except on the so-called Cerularius cross at Dumbarton Oaks, on which he is represented wearing the loros: R. J. H. Jenkins and E. Kitzinger, A Cross of the Patriarch Michael Cerularius, DOP 21 (1967), p. $235 \mathrm{ff}$. and figs. 1, 8. The interpretation of this object, which has no connection with Cerularius, would have benefited from a better acquaintance with Byzantine texts dealing with the miracles of St. Michael. For the iconography of the scene see A. Xyngopoulos,

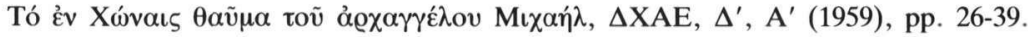

8. See, e.g., Theodoros Anagnostes, Kirchengeschichte, ed. G. C. Hansen, Berlin 1971,

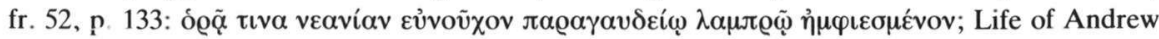
Salos, PG 111, 880A; Pantoleon, Miracles of St. Michael, ed. F. Halkin, Inédits byzantins

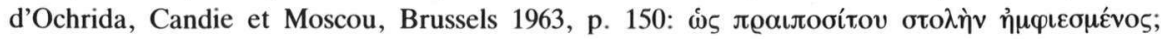

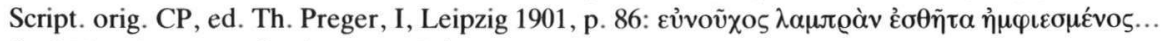

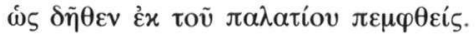


superstition $^{9}$, I came to the tentative conclusion that their imperial iconography originated outside the official Church, in some heretical or non-Christian milieu that I could not define more closely, and that this happened most probably in the course of the 5th century, i.e. after the constitution of narrative biblical illustration, but before the sermon of Severus, preached in about 512 . What I did not realize at the time was that the evolution of St. Michael was considerably more complex and bizarre. Quite by accident a different line of enquiry brought me back to this problem.

A few years ago I was occupied with a small puzzle, namely the date of the church of St. John of Studius at Constantinople, which is not only famous in the annals of Byzantine civilization, but also happens to be the only remaining - or half-remaining specimen of the Early Christian basilica in the eastern capital. The accepted date of this building used to be AD 463, but I happened to notice that an epigram in the Palatine Anthology $(I, 4)$, probably copied in situ from an inscription, stated that the founder, Studius, was rewarded for having put up the church of St. John by being named consul. Since he is known to have been consul in 454 , it followed that the church had to be earlier than that date - a simple matter and not one of great importance, except to students of Byzantine archaeology ${ }^{10}$. In the course of my investigation I came across two bits of extraneous evidence, of which one was known and the other not. The first was a scholion in the 10th-century lexicon known as the Suda, which stated that the same Studius also built a church of St. Michael at Nakoleia in Phrygia and quoted part of an epigram as having been inscribed in it ${ }^{11}$. Strangely enough, it was the same epigram as the one at Constantinople, minus the reference to St. John. Setting aside this odd duplication, there was nothing unlikely in the supposition that Studius built a second church at Nakoleia, and observations on the site seemed to confirm it. Nakoleia is now called Seyitgazi and is famous for the monastery (tekke) of Bektaşi dervishes that is built upon its hill. Within it is the supposed grave of Seyid Battal, the Moslem hero who fell fighting the Christians in 740. A considerable collection of Byzantine sculpture is to be seen in the courtyard of the Turkish complex, which may well occupy the site of St. Michael's church (Fig. 5) ${ }^{12}$, among them

9. See, e.g., M. Simon, Verus Israel, Paris 1948, p. $401 \mathrm{ff}$.

10. The Date of the Studius Basilica at Istanbul, Byz. and Mod. Greek Studies 4 (1978), pp. $115-122$

11. Ed. A. Adler, IV, 1935, p. 438.

12. See J. Kramer, Architekturteile des Seyitgazi-Tekke... und die Michaelkirche von Nakoleia, JÖB 22 (1973), pp. 241-250. The opuscule by Pantoleon, to be discussed presently, contains (Paris. gr. 1196, ff. 22v-23r) a story about a siege of Nakoleia by the Arabs (possibly in 782: Theophanes, ed. de Boor, 456.6), which makes it clear that St. Michael's church was a 

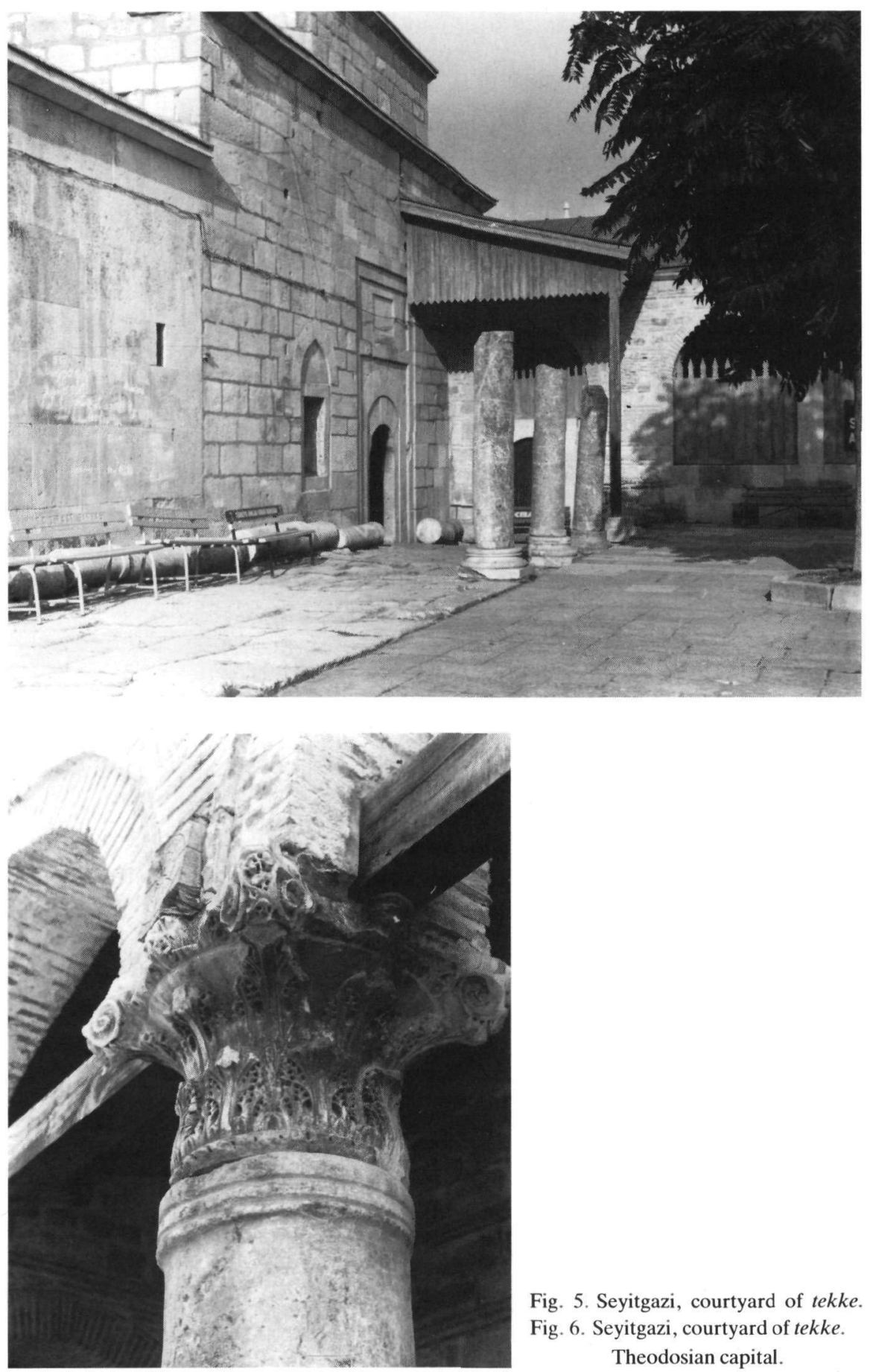

Fig. 5. Seyitgazi, courtyard of tekke Fig. 6. Seyitgazi, courtyard of tekke. Theodosian capital. 
a fine Theodosian capital (Fig. 6), not unlike those of the Studius basilica. The second bit of evidence proved harder to pursue. A casual reference by Du Cange ${ }^{13}$ suggested that Studius built yet a third church, also dedicated to St. Michael, at a place called Germia. The authority cited for this statement was a collection of Miracles of St. Michael by a certain deacon Pantoleon. Alas, this text turned out to be unpublished in full, except for a Latin version that said nothing about Studius ${ }^{14}$ and a number of individual passages in Greek $^{15}$. In view of the fact that Pantoleon's work is preserved in a great number of manuscripts ${ }^{16}$, I contented myself with consulting the one used by Du Cange (Paris. gr. 1196, olim Reg. 1473), which I collated with Paris. gr. 1510). Pending the appearance of a critical edition based on all available witnesses, the following text will have to suffice:

$\mathrm{A}=$ Paris. gr. 1196, saec. XI, ff. 24r-25r.

$B=$ Paris. gr. 1510, saec. $X$, ff. 97r-98v.

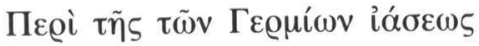

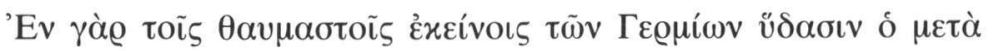

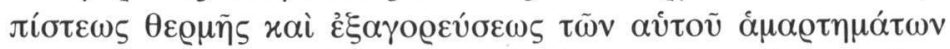

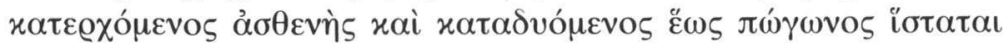

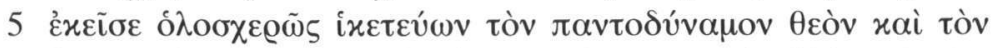

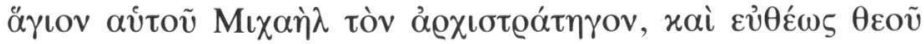

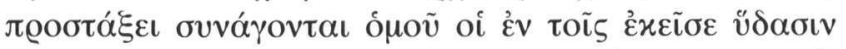

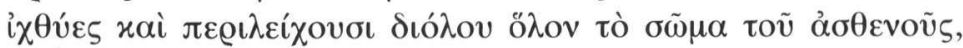

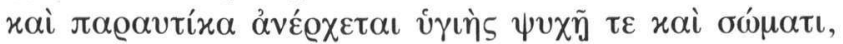

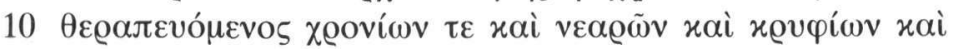

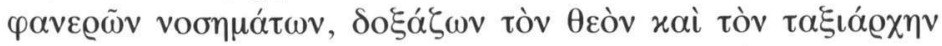

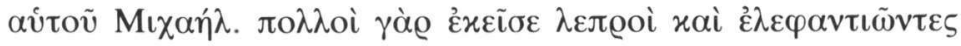

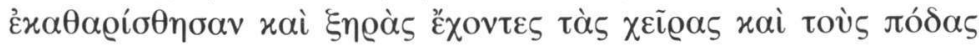

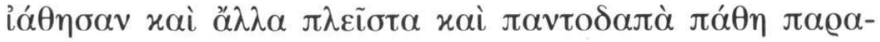

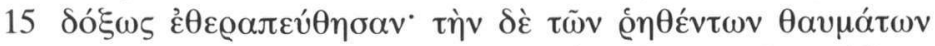

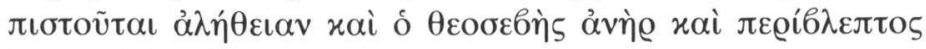

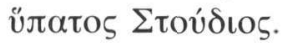

conspicuous landmark in the kastron. The seven column bases that are set in a row in the courtyard of the tekke (visible in our Fig. 5) need not, however, be in situ and are not equidistant from one another.

13. Constantinopolis Christiana, Paris 1682, lib. IV, p. 103.

14. PG $140,573 \mathrm{ff}$.

15. Halkin, Inédits byzantins, pp. 147-152. A short excerpt of the passage concerning Studius

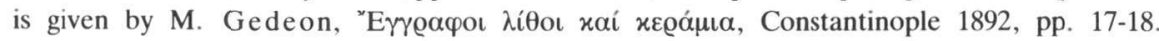
Pantoleon's work was known to Damaskenos Stoudites, who paraphrased parts of it in modern

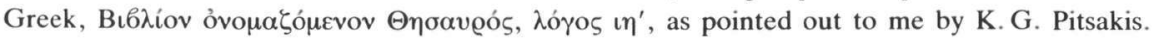

16. Six in Paris alone and fourteen in the Vatican, not to mention other libraries: see Halkin, Inédits byzantins, p. 147. 


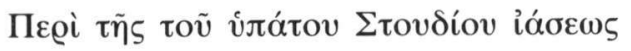

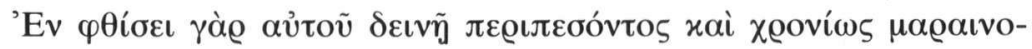

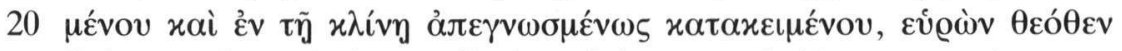

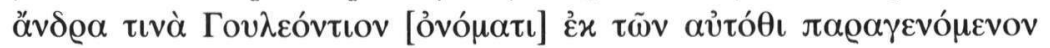

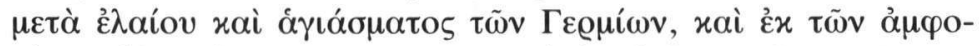

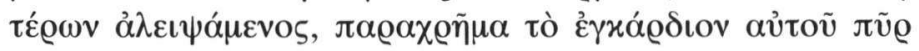

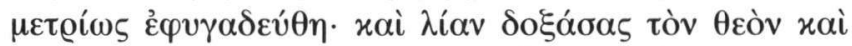

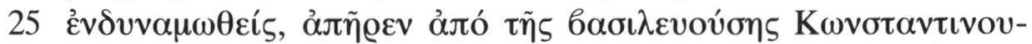

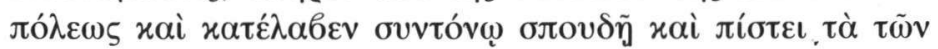

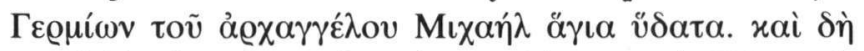

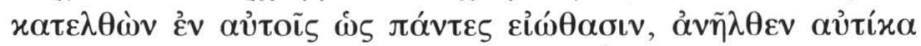

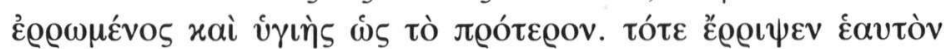

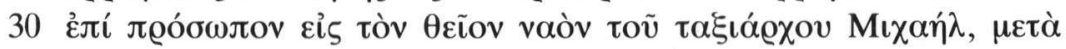

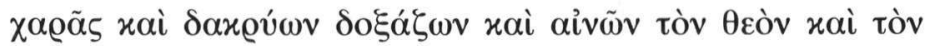

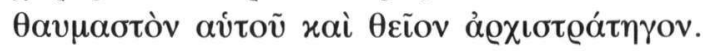

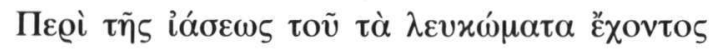

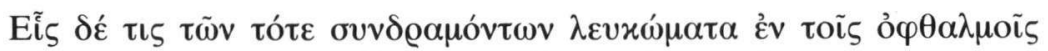

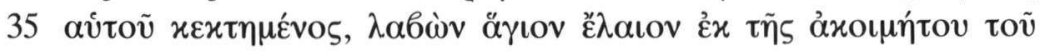

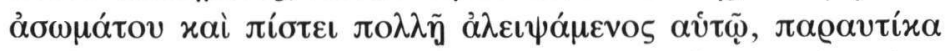

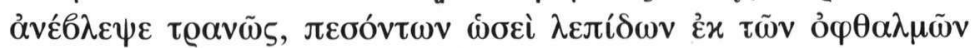

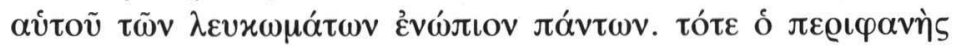

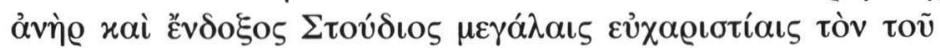

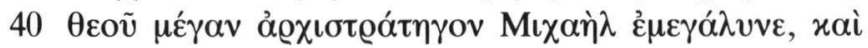

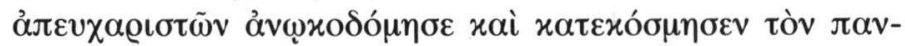

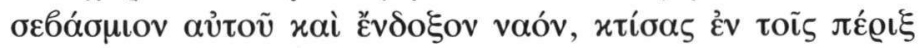

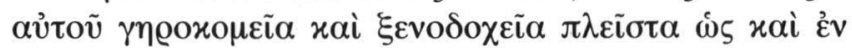

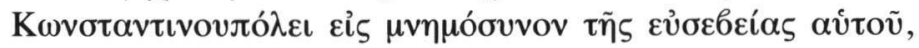

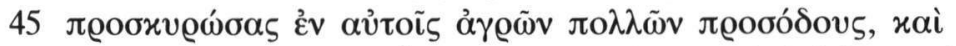

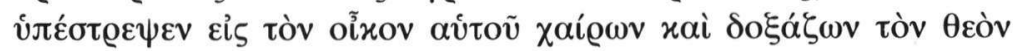

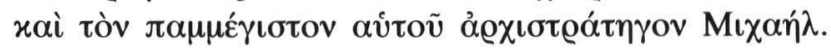

APPARATUS

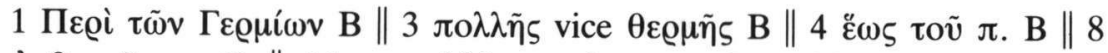

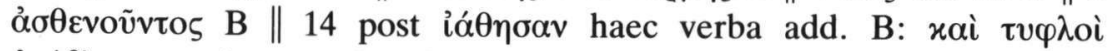

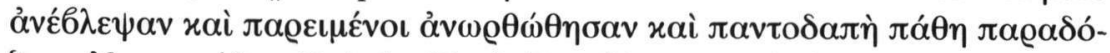

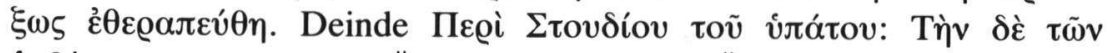

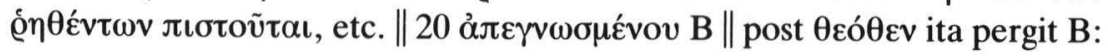




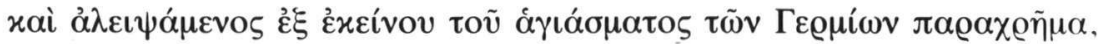

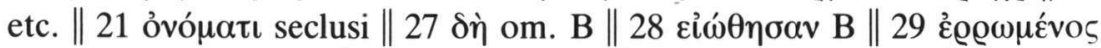

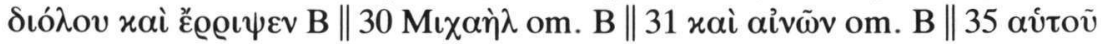

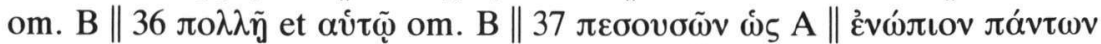

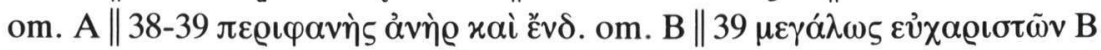

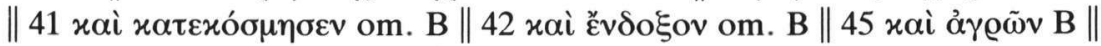

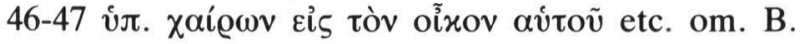

Before we address ourselves to the most curious feature of this text -a text, incidentally, that seems to date from the second half of the 9 th century ${ }^{17}$ - we should find out what else is known about Germia and where it was situated. No one doubts that Germia was in Galatia, not far from Pessinus. It is recorded that the Emperor Justinian went on pilgrimage there in 563, two years before his death ${ }^{18}$. A little later Gregory of Tours records that Christ's tunic was kept in the crypt of St. Michael's church ${ }^{19}$. Germia also plays a prominent part in the Life of St. Theodore of Sykeon, who, in about the year 600, performed his most spectacular mass exorcism there ${ }^{20}$. By the 7 th century Germia emerges as an autocephalous archbishopric, a rank appropriate to a famous pilgrimage centre, and remains so for the rest of the Middle Ages $^{21}$, although, to my knowledge, nothing further is recorded about $\mathrm{it}^{22}$.

The situation of Germia was established in 1936 by Henri Grégoire ${ }^{23}$ and confirmed more recently by the Austrian scholar Klaus Belke ${ }^{24}$ : it corresponds

17. As pointed out by me, The Date of the Studius Basilica, p. 118.

18. Theophanes, ed. de Boor, 240.12.

19. De gloria martyrum (composed c. 590), MGH, Scr. rer. Merov., I, 493. The location is given as "in civitatem Galateae, in basilica quae Ad sanctos archangelos vocitatur... in qua basilica est cripta abditissima". Although Germia is not mentioned by name, it is probably meant here. Cf. L. Duchesne, Communication sur les saintes tuniques vénérées au VIe siècle, Bull. de la Soc. Nat. des Antiq. de France 56 (1895), pp. 122-126.

20. Vie de Théodore de Sykéôn, ed. A.-J. Festugière, I, Brussels 1970, ch. 161. See also ch. 71, 100 (relics of St. George at Germia), 109.13, 167.31, 168.43.

21. So already in the Notitia of Epiphanius: J. Darrouzès, Notitiae episcopatuum ecclesiae Constant., Paris 1981, Not. 1.48. Cf. also 2.51, 3.66, 4.49 etc.

22. Apart from the mention of a monastery $\tau \tilde{\omega} v \Gamma \varepsilon \varrho \mu i \omega v$ or $\tau o \tilde{v} \alpha$ ó in the conciliar list of 787: R. Janin, Les églises et les monastères des grands centres byzantins, Paris 1975 , p. 437 , nos. $85,86$.

23. E. Honigmann, Pour l'atlas byzantin, Byzantion 11 (1936), p. 548.

24. Germia und Eudoxias, BYZANTIOC, Festschrift H. Hunger, Vienna 1984, pp. 1-11; K. Belke and M. Restle, Galatien und Lykaonien = Tabula imperii byzantini 4, Vienna 1984, pp. 166-168. 
to the modern village of Yürme that preverves the old name. I should also point out that $3 \mathrm{~km}$ south-west of Yürme lies a larger village called Holanta, clearly the same as the township of Goleounton mentioned in the life of St. Theodore of Sykeon as being very close to Germia ${ }^{25}$. The Goleountios who visited Studius at Constantinople was a native of Goleounton (nominative Goleous?): clearly, the villagers made a living by peddling in the capital the holy water and oil of the famous shrine situated in their vicinity.

In the 19th century several travellers stopped at Yürme and saw there the remains of a very large Byzantine church. The earliest, if I am not mistaken, was J. M. Kinneir ${ }^{26}$. At the close of the century came the German Karl Humann, who had been commissioned by the Berlin Museum to make a plaster cast of the Monumentum Ancyranum. He spent a miserable night among the villagers, whom he describes as the dirtiest and most uncouth he had ever seen; and when, the next morning he asked for a hot bath, expecting to find a hot spring for reasons of etymology $($ Germia $=\theta \varepsilon \varrho \mu \alpha ́)$, he was led to a pool of ordinary, cold water, perhaps the very same where St. Michael worked his miracles ${ }^{27}$. In 1898 came the Englishman J.W. Crowfoot, who, although he spent only two hours there on a very hot July day, was able to make a sketch plan and an elevation of the $\operatorname{church}^{28}$. He also took a few photographs. His plan is not very accurate, but does convey the enormous scale of the church, a five-aisled, vaulted basilica, nearly $50 \mathrm{~m}$. in length, its facade rising to a height of two stories, flanked by staircase towers that must have afforded access to the gallery. In spite of the growing interest in Byzantine architecture and the fact that Crowfoot's findings were reported and illustrated by Josef Strzygowski in his influential 'Kleinasien, ein Neuland der Kunstgeschichte' $(1903)^{29}$, no one else bothered to go to Yürme; and when, in 1981, I chanced to be passing through those parts, I had little expectation of finding any remains of the church. Surprisingly they were still very prominent, if sadly diminished since Crowfoot's visit (Fig. 7). As usual, the villagers have been gradually pulling them down to build their own houses. All I wish to say here about the ruins ${ }^{30}$ is that the church shows at least two structural phases

25. H. Grégoire, Goeléonta-Holanta, Byzantion 11 (1936), pp. 537-539, made the correct identification without recourse to the Life of Theodore of Sykeon.

26. Journey through Asia Minor, Armenia and Koordistan in the Years 1813 and 1814, London 1818, p. 49.

27. K. Humann and O. Puchstein, Reisen in Kleinasien und Nordsyrien, Berlin 1890, pp. 32-33.

28. Notes upon Late Anatolian Art, BSA 4 (1897-98), p. $86 \mathrm{ff}$.

29. Pp. 114-115. Crowfoot's previously unpublished photographs are reproduced as figs. 134, 136 (reversed), 137.

30. I hope to discuss them more fully elsewhere. 


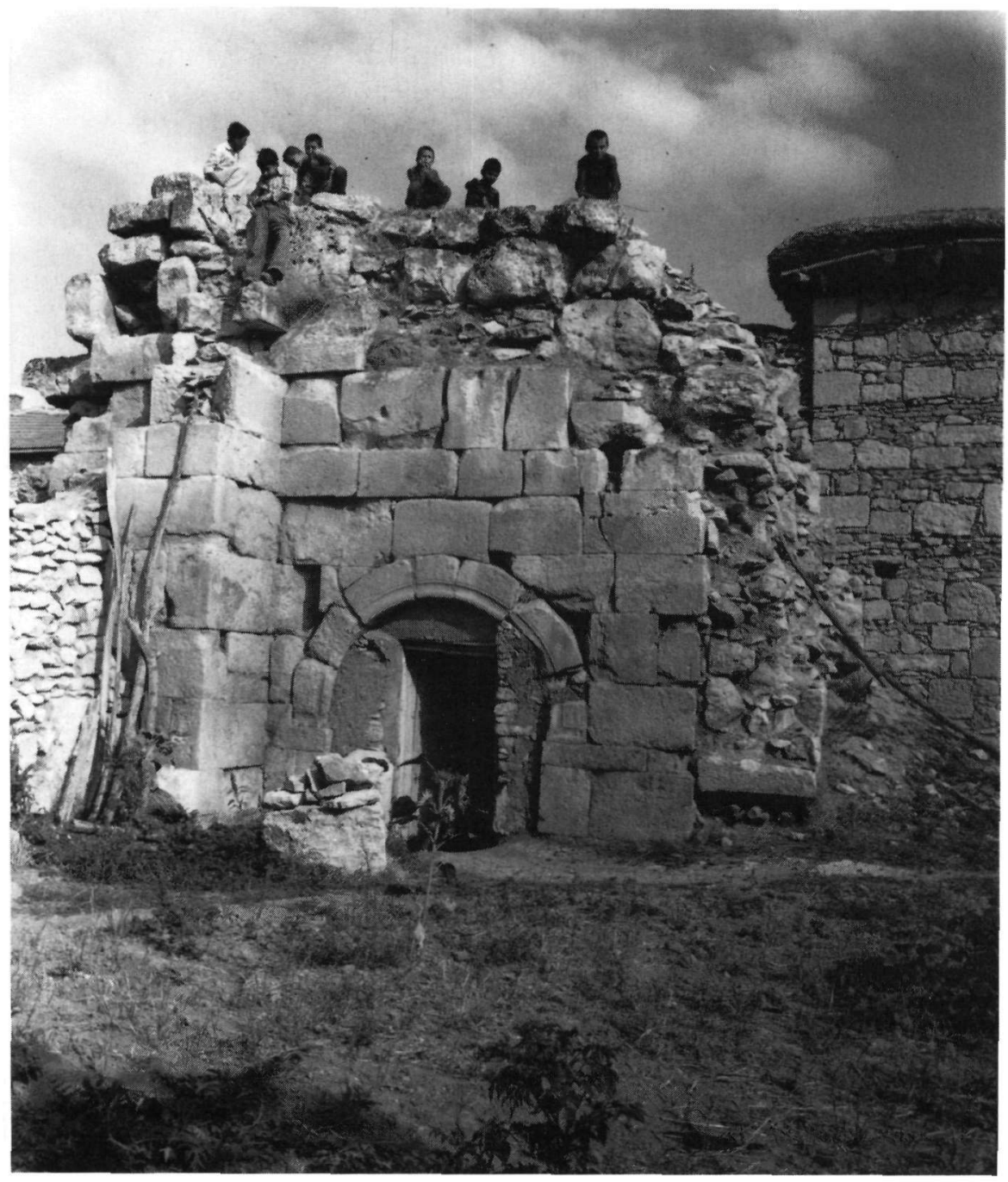

Fig. 7. Yürme, church of St. Michael. Detail of west façade.

(Fig. 8), of which the earlier one, in alternating bands of brick and stone, is probably of the 5th century, hence of the time of Studius, irrespective of the fact whether he was or was not its builder. It is also situated next to a ravine in which water once flowed, although it has now been diverted elsewhere. The village is still strewn with Byzantine carved elements and inscriptions, all of the 5th and 6th centuries, among them a capital bearing the monograms of 


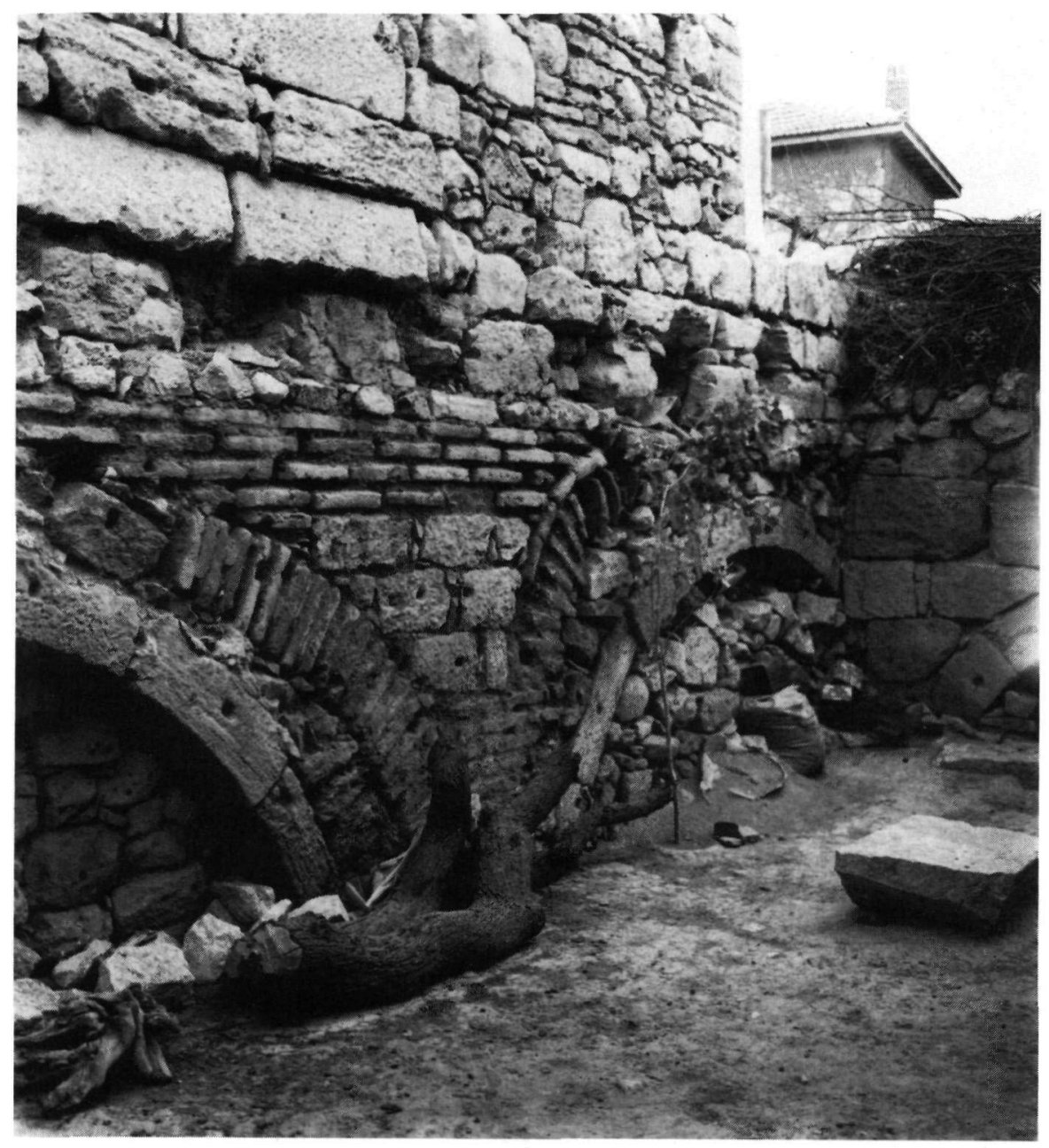

Fig. 8. Yürme, church of St. Michael. North crossing, showing two structural phases.

Justinian and Theodora (Fig. 9) ${ }^{31}$ and the fragments of an edict.

Interesting as the remains at Yürme may be for visualizing the arrangements of an early Byzantine pilgrimage centre, I should like to concentrate on another question, namely why it was that St. Michael performed his miracu-

31. Correctly identified by J. Strzygowski, BZ 9 (1900), p. 292; Kleinasien, p. 115. Justinian's monogram, though battered, is perfectly recognisable. Theodora's, now invisible because it is turned against a wall, is reproduced by Crowfoot, op. cit., fig. 6, who misread it as Eudoxia. 
Fig. 9. Yürme, Justinianic capital in front of village mosque.

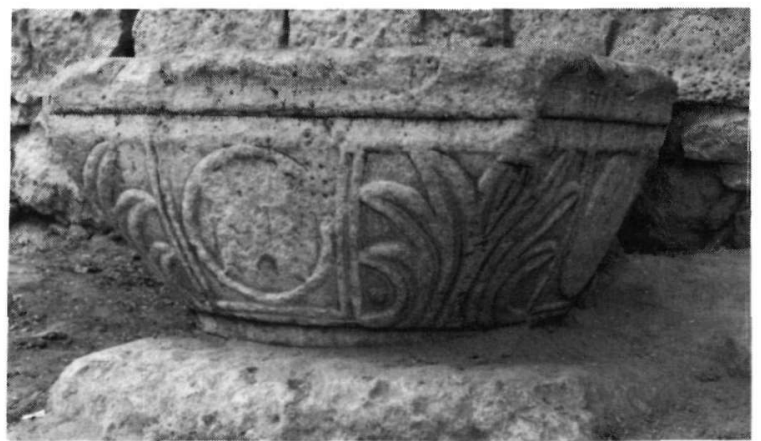

lous cures through the agency of a fishpool; for although, as we shall see, the Archangel had certain associations with water, he has never, to my knowledge, been linked with fish. The suspicion comes naturally to mind that he may have inherited an earlier, pagan cult. But whose? If we are to suggest any answers, we shall have to cast our net wider.

It is common knowledge that St. Michael as well as other archangels and angels enjoyed widespread veneration throughout western Asia Minor as far as Constantinople and the Aegean islands, as shown both by epigraphic evidence and church dedications ${ }^{32}$. It is also recognized that this phenomenon had a Jewish substratum, going back to the important colonies of Babylonian Jews established in Asia Minor since the Hellenistic period ${ }^{33}$. That this was so is shown by the fact that St. Paul, in writing to the Colossians (2.18), specifically warned them against the worship of angels. The same prohibition was repeated in the mid-4th century by the Council of Laodicea in Phrygia (canon 35). In the first half of the 5th Theodoret, in his commentary to the Epistle to the Colossians, stigmatized the worship of angels as a specifically

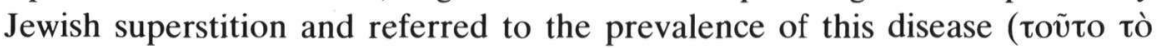
$\pi \alpha ́(\theta \circ \varsigma)$, as he calls it, in Pisidia, Lycaonia and neighbouring districts, i.e. in south-western Asia Minor ${ }^{34}$. The opposition of the established Church was of no avail. It is significant that the greatest Byzantine cult centre of St. Michael arose at Colossai, where the remains of a huge basilica were seen at the end of the last century by William Ramsay ${ }^{35}$. It is also interesting from the viewpoint

32. See, e.g., L. Robert, Hellenica 11-12 (1960), pp. 432-433.

33. Josephus, Antiquit. jud., XII, 3.

34. PG 82, 613 .

35. The Cities and Bishoprics of Phrygia, London 1895-97, pp. 214-215. He describes the ruins, which he saw in 1881 on the north bank of the Lycus, as being imposing and on a very large scale. Cf. id., The Church in the Roman Empire, London 1893, p. 479 and map facing p. 472, on which the site of the church is marked. F. V.J. Arundell, who first identified the site of Chonai, 
of our enquiry that the shrine of Colossai or Chonai, as it was commonly known, was associated with a miraculous spring ${ }^{36}$. Here, as elsewhere, St. Michael was first worshipped as a wonder-working healer, rather than as the Commander of the heavenly host ${ }^{37}$. A mass of amulets and magical papyri attest to the crucial role played by archangels at the level of popular superstition that was shared by Jews, pagans and Christians.

The association of St. Michael with a miraculous spring was not, therefore, an isolated case at Germia. But what of the fish? By and large, sacred fishponds are uncommon in Asia Minor, although a few scattered examples have been reported by travellers, one of them close to the area that concerns us, in the vicinity of Afyon Karahisar ${ }^{38}$. Sacred fish were more characteristic of Syria, as already reported by Xenophon ${ }^{39}$, and it was at Hierapolis/Menbidj that they were especially noted in the context of the temple of Atargatis. As far as I know, no fish have survived at Hierapolis, where the embankment of the sacred lake could still be observed at the beginning of this century ${ }^{40}$. But they have survived and are, indeed, doing very well at Edessa/Urfa, in what is today known as the pool of Ibrahim. They were seen there before the year 400 by the pilgrim Egeria ${ }^{41}$, which proves their continuous existence since antiquity. Quite probably the fish of Edessa were also sacred to Atargatis ${ }^{42}$.

It is generally acknowledged that the Syria Dea was the descendant of the great Anatolian Mother Goddess Cybele ${ }^{43}$, whose main cult centre lay at Pessinus, i.e. only a few miles from Germia. Indeed, we are dealing with an area that was charged with potent religious associations and one in which water

also reports that the remains of "a monastery dedicated to the Taxiarchs" were still visible: Discoveries in Asia Minor, London 1834, II, pp. 176-177. Cf. id., A Visit to the Seven Churches of Asia Minor, London 1828, p. 319 (information supplied by a Greek of Denizli). That the church was of basilical shape is suggested by the statement of Nicetas Choniates (Bonn ed., 523-524) that

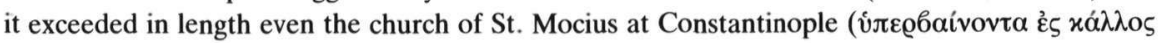

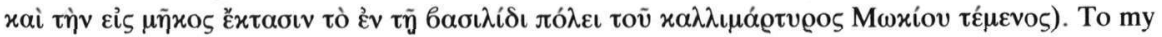
knowledge no remains are visible today.

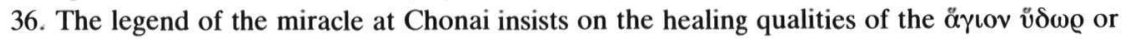

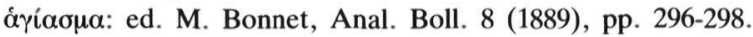

37. See, most recently, J. P. Rohland, Der Erzengel Michael Arzt und Feldherr, Leiden 1977.

38. On the way to Docimium: W. M. Calder, Julia-Ipsus and Augustopolis, JRS 2 (1912), p. 246. This is interesting because of the well-known connection of Attis with Docimium and the surrounding area: cf. L. Robert, A travers l'Asie Mineure, Paris 1980, p. 236.

39. Anab., I, 4, 9.

40. D. G. Hogarth, Hierapolis Syriae, BSA 14 (1907/8), pp. 187-189 and fig. 1. Cf. G.

Goossens, Hiérapolis de Syrie, Louvain 1943, p. 62.

41. Itin., 19.7.

42. Cf. J. B. Segal, Edessa, the Blessed City, Oxford 1970, pp. 48-49, 54-55.

43. See, e.g., Goossens, op. cit., p. 35 ff. 
played a prominent part. The river Sangarius, which flows in a great loop round Germia, was sacred to the worship of Cybele and personified in its mythology. At Pessinus itself the Belgian excavations have revealed, close to the temple, an elaborate canal ${ }^{44}$. The countryside round Germia is particularly well watered as all travellers have observed, and it is safe to assume that if a sacred pool had existed there before the advent of St. Michael it must have had something to do with the religion of the Great Mother.

I do not suggest, of course, that Cybele could have been transformed into the Archangel. But what of her companion Attis? Attis was a complex - one might say a somewhat fluid figure, whose characteristics underwent considerable development in the Roman period ${ }^{45}$, and in some respects he offers a closer analogy to Christ than to Michael: he was a shepherd, indeed, the good shepherd; he died and was reborn. In other respects, however, Attis would have had little trouble in transforming himself into an archangel. He was youthful and sexless as angels were regarded to be. He was a minister; indeed,

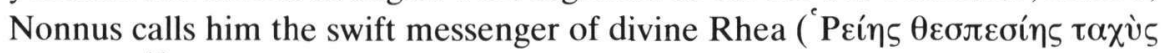
$\alpha \not \gamma \gamma \varepsilon \lambda \circ)^{46}$. He was a guardian of souls, invincible (invictus), an astral divinity. He was also represented as winged (Fig. 10). Could Attis have been the Anatolian predecessor of Michael?

Before we leave the plateau of Asia Minor we may take note of a very famous document, namely the late 2nd-century Abercius inscription. A whole library has been written on this topic ${ }^{47}$ and I have neither the intention nor the competence to re-examine it in all its complexity or to challenge the generally, though not universally accepted view that it is Christian. I shall only recall that the inscription was found a hundred years ago at Hierapolis in Phrygia

44. Résumé of 1970 campaign in Anatolian Studies 21 (1971), pp. 32-33; P. La mbrechts, La 6e campagne de fouilles à Pessinonte (1972), Türk Arkeoloji Dergisi 21/2 (1974), p. 79.

45. All the basic information may be found in H. Hepding, Attis, seine Mythen und sein Kult, Giessen 1903; H. Graillot, Le culte de Cybèle, Paris 1912; M.-J. Lagrange, Attis et le christianisme, Rev. bibl., NS 16 (1919), pp. 419-480; M. J. Vermaseren, The Legend of Attis in Greek and Roman Art, Leiden 1966. For the winged pilaster statue of Attis found at Cyzicus (now in the Istanbul Archaeological Museum, no. 3302) see Th. Macridy-bey and Ch. Picard, Attis d'un Métrôon (?) de Cyzique, BCH 45 (1921), p. 436 ff., also reproducing a fragment of a similar statue in the Russian Embassy on the Bosphorus.

46. Dionys., XXV, 313.

47. The earlier bibliography is given by A. Abel, Étude sur l'inscription d'Abercius, Byzantion 3 (1926), pp. 321-411. Among more recent contributions: H. Grégoire, Encore l'inscription d'Abercius, Byzantion 8 (1933), pp. 89-91; id., Bardesane et S. Abercius, ibid., 25-27 (1957), pp. 363-368; W. M. Calde r, The Epitaph of Avircius Marcellus, JRS 29 (1939), pp. 1-4; A. Ferrua, Nuove osservazioni sull' epitaffio di Abercio, Riv. Arch. Crist. 20 (1943), pp. 279-305; W. Wischmeyer, Die Aberkiosinschrift als Grabepigramm, JbAChr 23 (1980), pp. 22-47. 
Salutaris (west of Synnada) and that at some unspecified period, when it was still complete, perhaps in the 5th or 6th century, it was made the backbone of a roman hagiographique, the Life of St. Abercius, in which the text of the inscription is reproduced. The passage that concerns us, one of the most cryptic in the inscription, is in lines 12-15: "Faith led me everywhere and set before me fish from a source, very big, pure fish, caught by a chaste maiden, and constantly offered it to my friends

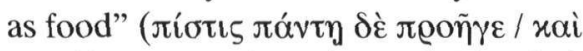

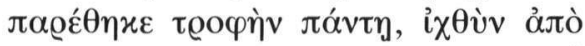

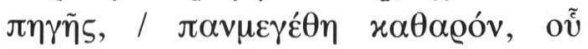

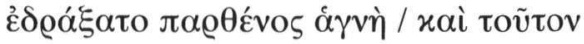

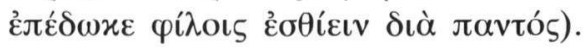
Those who believe the inscription to be Christian argue, of course, that the fish in question was the eucharistic sacrifice of Christ as icthys and that the chaste maiden was Ecclesia or the Virgin Mary. But why, it may be asked, was the fish caught in a source ( $\alpha \pi$ ò $\pi \eta \gamma \tilde{\eta} \varsigma)$ rather than in a river, a lake or the sea? To quote F. J. Dölger, “ 'Fisch von der Quelle' lenkt die Aufmerksamkeit des nicht eingeweihten Lesers zunächst auf die heiligen Tempelgewässer und heili-

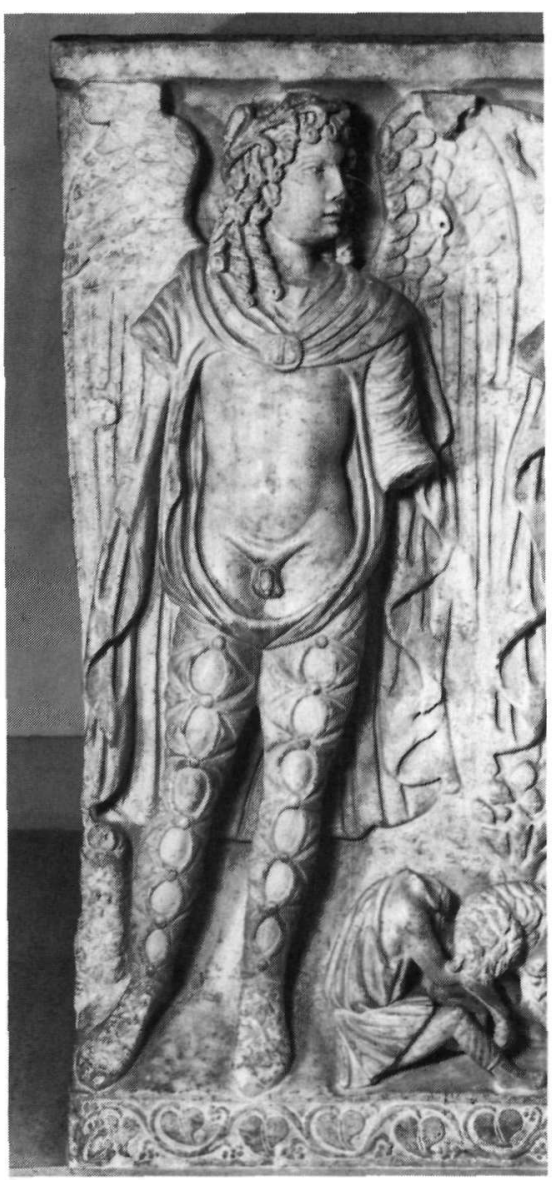

Fig. 10. Dumbarton Oaks, Season sarcophagus. Attis as Winter. Photo Dumbarton Oaks. gen Quellen mit den heiligen Fischen, die gerade in Kleinasien so häufig bezeugt sind" 48 . The only part of this statement that is not supported by the evidence adduced by Dölger is that sacred fishponds were common in Asia Minor. Now, however, we are in a position to cite an example that is not at all distant from Hierapolis and which ought to be added to the dossier of the inscription. The author of the funerary text may be said, therefore, to have had in mind certain local religious practices, a circumstance that leads us to a subtle remark by W. M. Calder: "Those who hold that the epitaph is Christian welcome every scrap of evidence 
which can be made to show that its language was the language which might have been used by a Phrygian pagan in the latter half of the 2 nd century AD. The fact that scholars of the standing of Dieterich and Hepding have taken the inscription to be pagan is a subtle compliment to the success with which its composer veiled his religion" 49 . I must confess that this kind of argument makes me a little uncomfortable. Can we be sure that Abercius intended to hide his religion rather than being, if not an outright devotee of Cybele and Attis, some kind of syncretist? Another small point: in the 'Vita Abercii' the only component that is neither a cliché nor embroidery on the inscription, the only component that appears to be based on local tradition, is that the Saint made a spring of hot water to gush out of the ground for the benefit of the sick and built a bathing establishment over it, an establishment that was still standing when the 'Vita' was composed ${ }^{50}$. So even if Abercius had been a proper Christian, all that remained of him after two or three centuries was a vague memory of a miraculous spring to set beside the one at Chonai or the one at Germia.

From Pessinus the religion of Cybele migrated to Cyzicus: even the name of the holy mountain, Dindymus, was the same in both places ${ }^{51}$. It was later asserted that the Argonauts established the cult of the Meter Dindymene. However that may be, when Constantine came along and set up his new capital, he is said to have removed the statue of Cybele from Cyzicus and made it into the Tyche of Constantinople after subjecting it to some alterations: the lions were taken away and the arms raised to an orant position. The story is in Zosimus $^{52}$, who may have taken it from Eunapius, although that cannot be proved. All we can be certain of is that about the year 500 there existed at Constantinople a statue identified as the Tyche of the city which was believed to have been that of Cybele; and it had been there for some time, since Julian had offered sacrifice to it in $362^{53}$. There was, therefore, some kind of connection between Cyzicus and Constantinople involving Cybele and the Argonauts, a connection of which we find several echoes.

In about the year 460 the temple of Cybele at Cyzicus was transformed into a church of the Virgin Mary and in the course of the alteration was found an inscription, which was an oracle delivered by Apollo prophesying the Virgin Birth and the revelation of the Triune God. We need not believe this, but it is

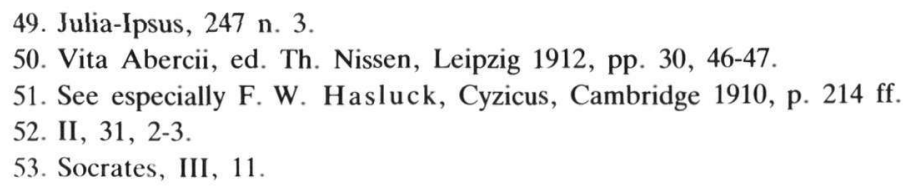


worth noting that the story was circulated very quickly since it is found in the Tübingen Theosophy whose original was composed before $491^{54}$. There was, therefore, a current of educated opinion at the time that sought to conciliate the new religion with the old. Now the oracle of Apollo had been allegedly sought by the Argonauts at a place called Pythia (modern Yalova) ${ }^{55}$ which was a famous hot spring not far from Constantinople. If there was a temple of Appollo there, as the name seems to indicate, it was inherited by St. Michael, whose church was earlier than the 6th century inasmuch as it was restored by Justinian $^{56}$. So, once again, we find Michael associated with a healing spring in succession to a pagan deity.

From Cyzicus the Argonauts proceeded to the Bosphorus, where they were attacked by a native chieftain called Amycus. Being in great fear, they sought refuge in a protected and overgrown bay and had a vision of a heavenly power in the form of a man who had wings like an eagle. The apparition foretold their victory over Amycus, whom they indeed defeated. In gratitude, they built a temple at the spot where they had seen the apparition and set up a statue of the winged power; and they called the place Sosthenion because they had been saved there. And when Constantine had come to Byzantium, he visited that spot and was struck by the strange aspect of the statue. That, he said, is an

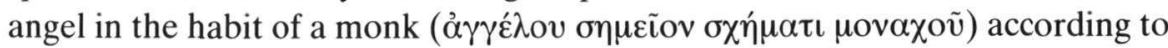
the Christian religion. He wished to know the angel's identity, which was revealed to him in a dream. He arose the next morning, set up a sanctuary facing the east and named the place after the holy archangel Michael. Such is the story told by Malalas in the 6th century ${ }^{57}$.

There is in this connection a topographical difficulty, which I cannot discuss at length ${ }^{58}$. Sosthenion corresponds to modern Istinye (Stenia to the Greeks), which forms the only deep natural bay on the European side of the Bosphorus. When Daniel the Stylite first came to Constantinople in about 455, it was there

54. K. Buresch, Klaros, Leipzig 1889, pp. 111-112.

55. Malalas, Bonn ed., 77.

56. Procopius, De aed., V, 3, 20.

57. Bonn ed., 78-79. Cf. John of Antioch, fr. 15 in C. Müller, FHG, IV, 548. The text of Malalas, as preserved in the unique Oxford MS, appears to be in need of some emendation. The

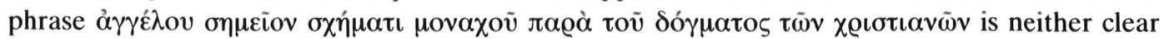

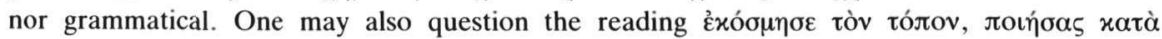

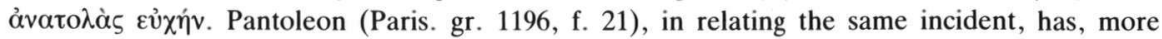

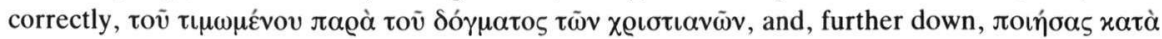

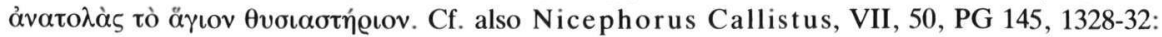

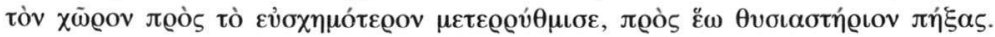

58. The fundamental topographical study by J. Pargoire, Anaple et Sosthène, Izv. Russk. Arheol. Inst. v Konst. 3 (1898), p. $60 \mathrm{ff}$, is in need of reconsideration. 
that he established himself in an abandoned pagan temple haunted by demons, next to a functioning shrine of St. Michael ${ }^{59}$. Sozomen, too, writing shortly before 450 , speaks of a renowned shrine of St. Michael on the European side of the Bosphorus, but the indication he gives -35 stadia, i.e. about $7 \mathrm{~km}$. from Constantinople by sea- is only half the distance to Sosthenion ${ }^{60}$ and would point either to modern Kuruçeşme or to Arnautköy. So, unless Sozomen's figure is incorrect ${ }^{61}$, we must suppose that two, equally famous churches of St. Michael were simultaneously in competition on the same side of the Bosphorus.

However that may be, the story told by Sozomen is of great interest. He claims that the Michaelion, as he calls it, was the most notable of Constantine's church foundations in the new capital and that the Archangel was believed to make himself manifest ( $\dot{\pi} \iota \varphi \alpha i ́ v \varepsilon \sigma \theta \alpha \iota)$ there. He himself had personal experience of this and he quotes the case of two of his contemporaries, one, a colleague in the lawcourts, who was healed there of a fever by a process of incubation, the other, a palace physician, whose shaky Christian faith was confirmed by a vision. Sozomen was, comparatively speaking, a serious historian and when he asserts that the Michaelion had been set up by Constantine, we can at least be reasonably certain that it was of some antiquity when he frequented it; so that even if we may hesitate to ascribe it to Constantine himself ${ }^{62}$, we can hardly doubt that it dated from the 4 th century. That would probably make it the most ancient among the attested and documented shrines of St. Michael in the Christian world.

This conclusion is of some importance, for the Michaelion on the Bosphorus was not some obscure church in the back country of Asia Minor, surrounded by a rustic population of dubious orthodoxy. It was on the

59. Life of Daniel, ed. H. Delehaye, Les saints stylites, Brussels 1923, paragraphs 13, 15, 17. It should be noted that this document speaks only of Anaplous. The fact that Daniel's column (distant 1 mile from St. Michael's) was on the hill above Sosthenion is stated in the Life of St. Luke the Stylite, ed. F. Vanderstuyf, Patr. orient., XI/2, 51. Cf. R. Ja nin, La géogr. eccl. de l'Empire byzantin, I/3, 2nd ed., Paris 1969 , p. 347.

60. II, 3, PG 67, 940B-C. The distance from Byzantium to Sosthenion is given as 80 stadia in Anon., Periplus Ponti Euxini, Müller, Geogr. gr. min., I, 422.

61. It is, however, confirmed by the Latin version of Cassiodorus-Epiphanius, Hist. tripartita, II, 19. Note also that the site of Sozomen's Michaelion was originally known as Hestiae,

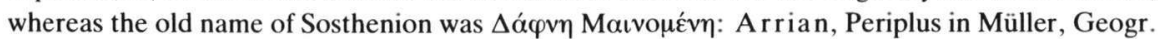

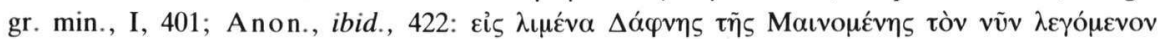
$\Sigma \omega \sigma \theta \varepsilon ́ v \eta v$. This has already been noted by K. Lübeck, Zur ältesten Verehrung des hl. Michael in Konstantinopel, Hist. Jahrbuch 26 (1905), pp. 773-783.

62. Cf. G. Dagron, Naissance d'une capitale, Paris 1974, p. 396, who admits "un rapide travestissement d'un rite païen en rite chrétien au temps peut-être de Constantin”. 
doorstep of the capital, its foundation was ascribed to imperial initiative and it drew its clientèle among distinguished lawyers and physicians. How is it then that the Michaelion, with its supernatural manifestations and cures by incubation, was tolerated at the very time when the Church laid stress on condemning the worship of angels and the dedication of churches to them? Can it be true, after all, that the Michaelion had been founded by Constantine? A precise occasion comes naturally to mind: in September 324 Constantine, at the head of his troops, crossed the Bosphorus before defeating his rival Licinius at Chrysopolis ${ }^{63}$. In the course of this war he is said to have had several visions announcing his victory $^{64}$. Or did he take to his credit the vision of an angel which Licinius had had a few years previously (313), prior to his victory over Maximinus Daia at Campus Ergenus, not far from Byzantium $^{65}$ ?

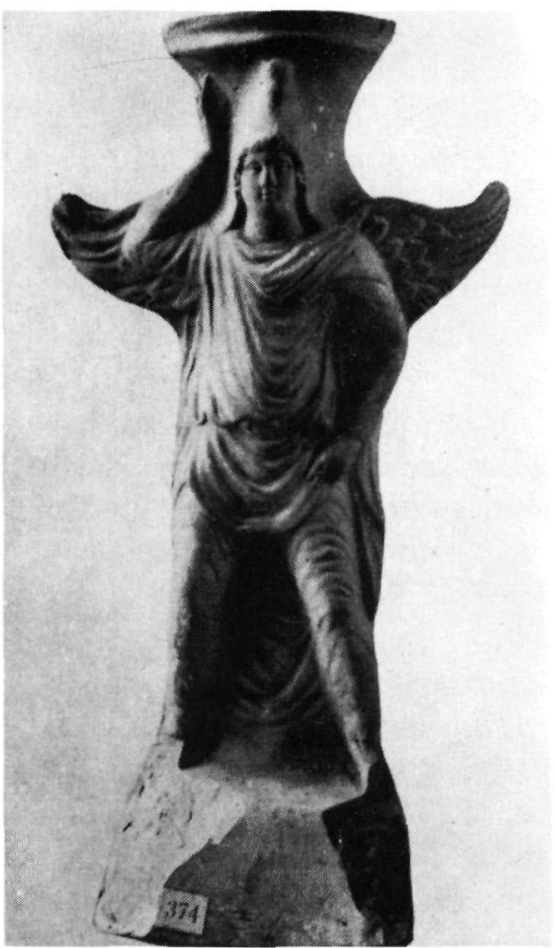

Fig. 11. Louvre, statuette of Attis. Photo Musée du Louvre.

I come back to a point that I find especially intriguing: the statue of a winged deity in the habit of a monk. This detail has been duly noted by earlier scholars, who have been, however, unable to discover any likely explanation in ancient art or mythology; hence the suggestion that it may have been some kind of votive image ${ }^{66}$. Yet, it seems to me that an identification can be made. Monastic garb indicates the presence of a cowl or some other headgear looking

63. Zosimus, II, 26, 1.

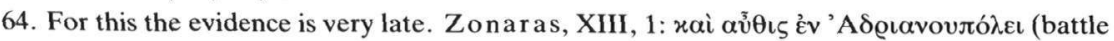

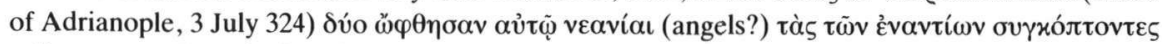

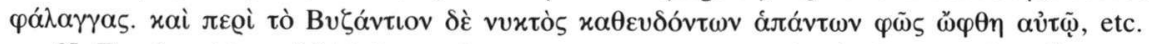

65. For the vision of Licinius we have contemporary attestation in Lactantius, De mort. pers., 46, ed. J. Moreau, Paris 1954, p. 129: Licinio quiescenti adstitit angelus dei, who taught him the words of the prayer, Summe deus, te rogamus, sancte deus, te rogamus.

66. See E. Lucius, Die Anfänge des Heiligenkults in der christlichen Kirche, Tübingen 1904, p. 269; Lübeck, op. cit.; G. F. Hill, Apollo and St. Michael, JHS 36 (1916), p. 157: "No one has yet succeeded in explaining what kind of Greek statue can have been mistaken by anybody for an angel in monk's clothing". 
like a cowl: the statuette reproduced in Fig. 11 gives the answer. It is that of a winged Attis, not exposing his naked body as elsewhere, but fully draped and wearing the Phrygian cap ${ }^{67}$.

This brings us back full-circle to Germia and Pessinus. It also establishes a curious parallelism. The Argonauts, after setting up the worship of Cybele at Cyzicus, see a vision of Attis on the Bosphorus, announcing their victory over Amycus. At the same spot Constantine is said to have beheld a vision of a winged being, presaging, perhaps, his victory over Licinius.

The conclusions we may draw from our enquiry are, I believe, of general interest for the topic of religious survivals. Of course, St. Michael is not Attis any more than he is Apollo ${ }^{68}$ : he belongs squarely to the world of Judaism, and more to that of Jewish-Babylonian magic than to the Bible; which is why his original role in Christianity, a role condemned by the official Church, was that of healer and guardian against the occult powers of evil. The essential thing was to know his name, as well as those of the other archangels, and to call on

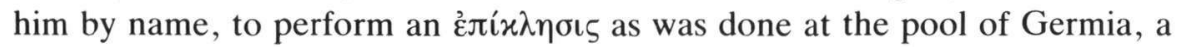

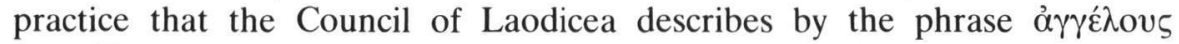

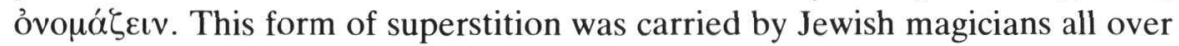
the Mediterranean world, but it became especially rooted in western Asia Minor, where it met a very ancient local cult, that of Cybele and Attis, a cult that had its holy places associated with mountains and springs of water. And so, in this particular geographical area, a fusion took place. Not that St. Michael could assume the major cult centres of the old religion, like Pessinus, which was still a going though declining concern ${ }^{69}$ but in some other places, where there was a Jewish settlement -and, significantly, a Jewish colony is attested at Goleounton ${ }^{70}$ - Michael could easily substitute himself for Attis. The advent of Christianity complicated even further a situation that was sufficiently confused. The Church had little use for Michael, the patron of the people of Israel, and, after trying in vain to eject him, took the easier expedient of absorbing him: after all, Michael does figure in the book of Daniel and, with little effort, he could be identified with the angel that appeared to Joshua, the angel that struggled with Jacob, even the healing angel who troubled the water of the pool of Bethesda (Jn 5.4). Perhaps

67. Louvre, inv. no. T 61, from Tarsus. See Musée Nat. du Louvre, Catal. des figurines et reliefs en terre-cuite, III (by S. Besques), Paris 1972, no. D 2291, p. 283; Vermaseren, The Legend of Attis, p. 14 and pl. IV 1.

68. For the analogies between Apollo and St. Michael see Hill, op. cit., p. 134 if.; F.W. Hasluck, Letters on Religion and Folklore, London 1926, pp. 84-86.

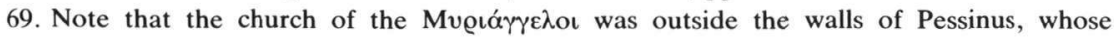
cathedral was dedicated to St. Sophia: Vie de Theodore de Sykéôn, ch. $101.37 \mathrm{ff}$.

70. Ibid., ch. 161.95 . 
Constantine played, unwittingly, a role in the process: later legend ascribed his conversion to Michael's intervention ${ }^{71}$. By the 5th century, in any case, Michael was firmly established and a multitude of churches rose in his honour, even one in the imperial palace of Constantinople ${ }^{72}$, thus setting on him the seal of official approval. He was also ready for export to the West where, in accordance with his characteristics in Asia Minor, he took up residence on mountain tops and in deep ravines, in caves where a miraculous water trickled out of the rock, from Monte Gargano to Mont Saint-Michel.

The composite St. Michael that emerged in eastern Christianity was, as might have been expected, an ill-defined figure. The iconography that was devised for him in the 5th century and which provided our starting point, spoke clearly to contemporaries and showed that he was much more than a minister of the Lord -indeed, a kosmokrator in his own right, as Sol and Attis invictus had been before him. Along with his colleague Gabriel, he mounted guard on the Virgin Mary, the successor of Cybele. No wonder that the medieval Byzantines had so much trouble in explaining this iconography, which, in their conservatism, they nevertheless preserved.

71. This is surely significant for the interpretation of the Cerularius cross, on which see above, note 7.

72. Before c. 500. See Janin, op. cit., p. 344, who neglects to quote its mention in the Acts of the Council of 536: Acta Conc. Oecum., III, 159, 160, 175. For the diffusion of churches dedicated to St. Michael see P. Canivet, Le Michaelion de Hūarte, Byzantion 50 (1980), pp. 85-117. 